\title{
THE MATHEMATICAL MODEL FOR ESTIMATING THE PROBABILITY OF RISK OF INCOMPETENT SPECIALIST GRADUATION
}

\section{Ganna Khimicheva ${ }^{1}$ \\ Antonina Volivach ${ }^{2}$}

DOI: https://doi.org/10.30525/978-9934-26-001-8-2-12

Abstract. The article presents the results of research for the mathematical model for estimating the probability of risk of incompetent specialist graduation.

The mechanisms and tools to determine the probability of risk of incompetent specialist graduation have been developed in the course of the research. The goal tree method has been used as a mechanism to determine the relationship between the structural components of the educational process and the educational program. Using this method, the structuring of 9 criteria by which the educational program quality is evaluated has been carried out. That is, its strengths and weaknesses have been identified. In turn, as a tool for estimating the probability of an educational process (educational program) risks and the graduation of an incompetent specialist, it has been proposed to use a regression mathematical model.

To build a mathematical model, an active experiment, a qualimetric approach, a method of regression analysis, and 16 conditional educational programs that met the "Standards and Guidelines for Quality Assurance in the European Higher Education Area" (ESG) have been used. The construction of the model has been carried out according to a specially designed scheme, which included 5 stages.

In the first stage, a group of experts was formed and their consistency was determined with the help of the "HEI Experts" software.

In the second stage, six groups of indicators were identified, which further estimated the educational process (educational program) quality.

\footnotetext{
${ }^{1}$ Doctor of Technical Sciences, Professor of the Department of Computer-integrated Technologies and Measuring Technique, Kyiv National University of Technologies and Design, Ukraine ${ }^{2}$ Senior Lecturer, Department of Computer Science and Technologies, Kyiv National University of Technologies and Design, Ukraine
} 
For this purpose, the experts used the method of pairwise comparison to select 9 unit indicators, which further estimated the levels of compliance of 16 conditional educational programs. The estimation was conducted according to standardized quality indicators that are inherent in the real educational process (educational program).

In the third stage, a robust plan of the experiment was constructed using the method of pseudo-random LP- $\tau$ numbers uniformly distributed in multidimensional space. According to the plan, a working matrix of the experiment was formed. Then, the group of experts formed in the first stage carried out the percentage estimation of the probability of risk of incompetent specialist graduation.

In the fourth stage, a mathematical model was built using the PRIAM (planning, regression, and model analysis) software. This model allows us to assess nine factors that affect the probability of risk of incompetent specialist graduation.

In the fifth stage, the statistical characteristics of the model were tested. According to the test results, it was proved that the model is informative, adequate, and stable, both in terms of structure and calculations. At the same stage, the marginal surfaces were constructed and the forces of influence of regressors (indicators) on the probability of risk of competent/incompetent specialist graduation were determined.

According to the results of research, it has been proved that such indicators as compliance of the applicants (bachelors) level with the second Master's level and the level of considering labor market employers (stakeholders) requirements have the strongest impact on the competence of the future specialists.

The proposed model allows us to estimate the factors influencing the efficiency (effectiveness) of the educational process and to determine the probability of the risk of competent/incompetent specialist graduation.

\section{Introduction}

According to the current legislation of Ukraine and "Standards and Recommendations for Quality Assurance in the European Higher Education Area" (ESG) [1], the main regulatory document of the educational process is the educational program (OP). It regulates the requirements for educational components aimed at achieving program learning outcomes 
and obtaining appropriate qualifications. However, during the acquisition of competencies, there is a possibility of risks associated with the organization and the educational process. This generally leads to a decrease in the level of quality of the future specialist.

The analysis of literature [2-5] shows that the risks are inherent in any field of activity. They are usually due to the influence of internal and external environments on the activities in which the enterprise (institution) operates. The peculiarity of the educational process risks is that they are directly the bearers of potential risks for any sector of the economy or production. This is because any activity of the enterprise (institution) is associated with the use of knowledge and competencies of specialists (graduates of educational institutions).

According to the methodological recommendations [6], the educational program is based on a competency approach. In turn, the competence of specialists depends on the quality of the educational program. Therefore, the application of methodological recommendations [6] guarantees the quality of the structural components of the program and allows us to determine the effectiveness of training and the level of competence of the future specialist.

It is known that for the second master's level the main general competencies that form a competitive specialist and his professional skills according to [6] are program competencies. The last ones are divided into integral competence and general and professional competencies.

Integral competence forms the ability to solve complex problems and problems in the relevant field of professional activity, to conduct research using innovations in uncertain conditions and research requirements.

Common competencies are knowledge, understanding, skills, and abilities that are universal. They are obtained within a specific educational program and provide additional (often crucial) employment prospects. They are divided into instrumental, interpersonal, systemic [6].

Among the general competencies the following ones should be distinguished: ability to apply knowledge in practice; ability to search, process, analyze and manage information; ability to adapt to new situations; concern for quality; readiness for independent work; ability to work in a team; ability to solve organizational issues and plan the work; ability to speak the state language in oral and written forms; interpersonal skills.

Professional competencies are the key to obtain any level of higher 
education. They depend on the professional field and need constant review following the requirements of the national economy and stakeholders.

Therefore, to improve the educational program and determine its priority goals and competencies of future specialists, it is expedient for higher education institutions (HEIs) to monitor, periodically review and update their programs. This enables to organize the educational process at the appropriate level and helps to create an effective educational environment for students.

Evaluation of educational programs is performed in the following sequence [1]: checking the EP for compliance with modern requirements and the latest research in the relevant field of knowledge; taking into account the modern needs of society; effectiveness of EP; effectiveness of student assessment procedures; compliance of the educational environment and educational services with the program goals.

In works [7-9], it is shown that the activities of free economic education, educational process, educational program, and the level of competencies acquiring by future professionals are affected by risks. Therefore, to prevent them, it is necessary to develop timely organizational and technical measures to reduce them. In international practice, this uses integrated management systems based on the risk management principles and the requirements of ISO 9001 and ISO 31000. This approach minimizes the risks of educational activities and increases the competitiveness of higher education institutions in general.

The authors' analysis of the literature [10-13] has shown that in most of them the risks are assessed only by qualitative characteristics. However, this does not allow us to obtain reliable information and evaluate their consequences. One of the ways to solve this problem is to use methods of regression analysis and build multifactor models based on them.

Many scientists have dealt with the application and improvement of regression analysis methods. For example, Herl [14] proposed to use the ridge regression method as such a mechanism. This approach reduces the standard errors during calculations. At the same time, the issues of structural stability of the models remain unresolved. The results of the research presented in [15] allow us to partially solve these questions. To do this, the author proposes to use algorithms for generating experiment plans RASTA1, RASTA2, RASTA8, and use them to solve various types of problems. 
In [16], the conditions allowing to formalize experimental researches at the construction of multifactor models have been presented. In particular, the requirements for stable (robust) experimental plans, sustainable patterns, multifactor statistical models, and the stability of the model coefficients have been formed. These approaches can be used in any field, including the construction of multifactor models of educational processes in higher education.

In [17], the authors propose a methodology for the application of multifactor regression analysis to study and construct high-precision statistical models. The use of these models allows establishing causal, structural, and quantitative relationships between a group of controlled factors and the simulated criteria of the studied processes. That is, to increase the efficiency of selecting the evaluated processes parameters. In general, this approach can be used to evaluate the educational process and educational programs.

In [18], on the example of machine-building enterprises, it has been proved that multifactor models allow to estimate and forecast both volumes of production, and to define the factors influencing the probability of risks and efficiency of the enterprise activity as a whole.

In [19], the author proposes to use multifactor models to study the technological processes of metal processing. The use of model data allows us to explore some characteristics of the parameters of technological processes. However, it does not evaluate the effectiveness of the process as a whole.

In [20], the principles and approaches on the construction of multifactor regression models for optimization of technological processes and improvement of technical, measuring, materials science systems have been given. In particular, for these purposes, the author proposes to use PRIAM software. This allows you to first build matrices, and then develop regression models based on them. Then with the help of these models to optimize the parameters of technological processes and determine the most important of them. It should be noted that these results can be applied in any production area. However, to apply them in education, they need to be refined in terms of specific educational activities features of higher education institutions.

In [21], it is proposed to use multifactor models for quantitative risk assessment. The advantages of these models are that they allow you to 
assess the potential for risks and determine their impact on the activities of the enterprise (institution). However, for higher education institutions to use the models presented in the work, there is a need for special research related to determining the risk factors of the educational process (educational program), which affect the formation of a future specialist competence.

The authors of $[22 ; 23]$ propose to use mathematical modeling in the form of a cyclic process, in which it is necessary to perform all cycles in stages. That is, to clarify the problem according to the previously obtained results and thus adjust the mathematical model. This approach is quite promising, so it is advisable to use it to model any technological and production processes, including educational.

In [24], the principles and approaches of construction of multifactor regression model of personnel subsystem management are given. The author proposes to take into account such factors as: the prestige of the employer; career opportunity for the employee; the level of partnership between the company's management and staff; material and social incentives for highly productive work; information architecture of the enterprise; general assessment of the internal image of the enterprise. These principles, in our opinion, can be used to assess educational processes, in particular their components related to research and teaching staff. However, when building regression models, it is advisable to use an information approach that allows you to more objectively and accurately determine the factors that underlie the model.

Therefore, the research related to assessing the risks of the educational process (educational program) by building a multifactor model and determining their impact probability on the future professional graduating are relevant and timely.

The object of the study is the process of building a multifactor model to evaluate the probability of risk of an incompetent specialist graduation.

The subject of the study is the regularities of the choice and substantiation of the factors that determine the risks of the educational process (educational program) and influence the graduation of the future specialist.

The methodological basis of the research is a systematic approach to the study of research objects. Experimental studies were based on the expert and regression analysis methods. MS Excel, VBA for application, PRIAM software products have been used for calculation. 
The study aims to build a multifactor regression model to estimate the probability of the educational process (educational program) risks and determine their impact on future professionals' graduation.

Main task. To achieve this goal following tasks have been solved:

- the correlation between the structural components of the educational process (educational program) and factors that are risks bearers;

- the experiment plan has been selected and the matrix of the experiment has been constructed;

- the requirements have been developed and a conditional educational program has been formed, based on which the probability of the risk of a competent/incompetent specialist graduation has been studied;

- with the help of PRIAM software a multifactor regression model has been built.

\section{The results of experimental studies}

The Kyiv National University of Technology and Design has been conducting some studies in recent years related to the assessment of the risks of educational activities (educational program). The results of the research allowed us to classify and structure risks by external and internal factors [25], to determine the weight and probability of risks, to develop recommendations for choosing the methods for their assessment, and to propose organizational and technical measures to minimize them [26].

Given the fact that the educational process is based on a particular educational program, there is a need to estimate their mutual impact and the potential for risks. However, for this, first of all, it is necessary to know the mechanism of structural components of the educational process interrelation with the requirements according to which the educational program is evaluated [27]. Second, have the tools to estimate them, such as multifactor mathematical models.

In the research, the goal tree method has been used as a mechanism to determine the correlation between the structural components of the educational process and the educational program. Using this method, the structuring of the nine criteria has been performed. According to the criteria, the quality of the educational program is estimated [27]. That is, its "strengths" and "weaknesses" have been determined. 
For example, the first "Design and objectives of the EP" criterion has been structured on two levels (Figure 1).

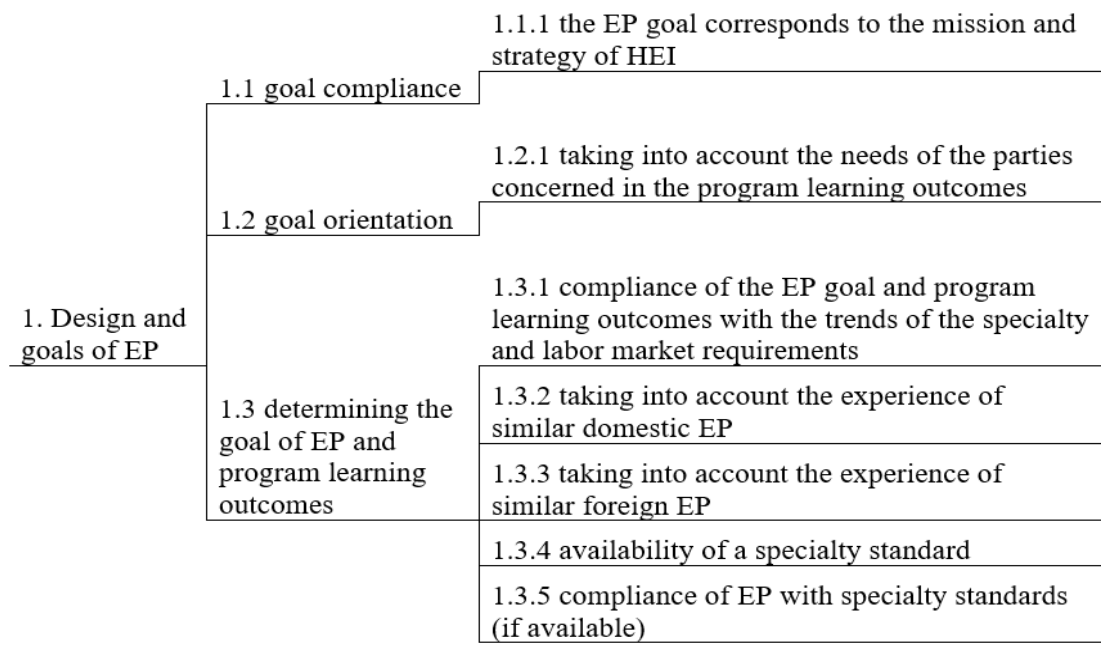

\section{Figure 1. Structuring the "Design and goals of EP" criterion}

As can be seen from the figure, the first level has three sub-criteria:

- compliance with the goal;

- goal orientation and definition of the EP goal and program learning outcomes.

The second level has seven unit indicators:

- the EP goal corresponds to the mission and strategy of HEI;

- taking into account the needs of stakeholders in the program learning outcomes;

- compliance of the EP goal and program learning outcomes with the trends of the specialty and labor market requirements;

- taking into account the experience of similar domestic EP;

- taking into account the experience of similar foreign EP;

- availability of the specialty standard and compliance of the EP with the specialty standards (if any).

The other eight criteria were similarly structured and the following results have been obtained: where the second criterion has 9 sub-criteria and $14-$ 
single indicators; the third criterion - 3 sub-criteria, 6 - single indicators; fourth criterion - 5 sub-criteria, 15 single indicators; fifth criterion -3 subcriteria, 5 single indicators; sixth criterion -5 sub-criteria, 9 single indicators; seventh criterion -6 sub-criteria, 14 single indicators; eighth criterion -2 subcriteria, 2 single indicators; ninth criterion -2 sub-criteria, 2 single indicators.

Thus, according to the research results, it is proved that it is expedient to evaluate the quality of the educational program according to 9 criteria, 39 sub-criteria, and 74 single indicators. This allows us to determine the influence of factors on the efficiency and effectiveness of the educational process and to identify the "weaknesses" and "strengths" of the educational program, which are potential risks bearers.

To determine the potential for risks of the educational process, which directly affect the formation of future professionals' competence, a typical scheme used in the source [9] has been applied. It is designed in accordance with the requirements of ISO 9001 and 3100, which are adapted to determine the risks of any process, including education. The algorithm for risk assessment based on the requirements of DSTU ISO 31010: 2013 is given in the source [28].

It should be noted that this scheme takes into account the sources of input, the educational process itself, and its results, taking into account the requirements of employers (stakeholders). For further research, the scheme was adapted for the second master's level of higher education (Figure 2).

According to this scheme, the educational process consists of five components, such as: designing training according to the educational program; material and technical resources; academic staff; scientific activity and educational work.

Each of the components affects the efficiency (effectiveness) of the educational process and requires monitoring. In the future, based on the results of monitoring, it is advisable to develop and implement organizational and technical measures aimed at improving and updating both the educational process and the educational program as a whole. This, in turn, will increase the competence and demand of future professionals in the labor market and the competitiveness of higher education.

The above results were used later in experimental studies to build a mathematical model.

It has been proposed to use a regression mathematical model as a tool to estimate the probability of risks of the educational process (educational program). 


\section{Chapter «Engineering sciences»}

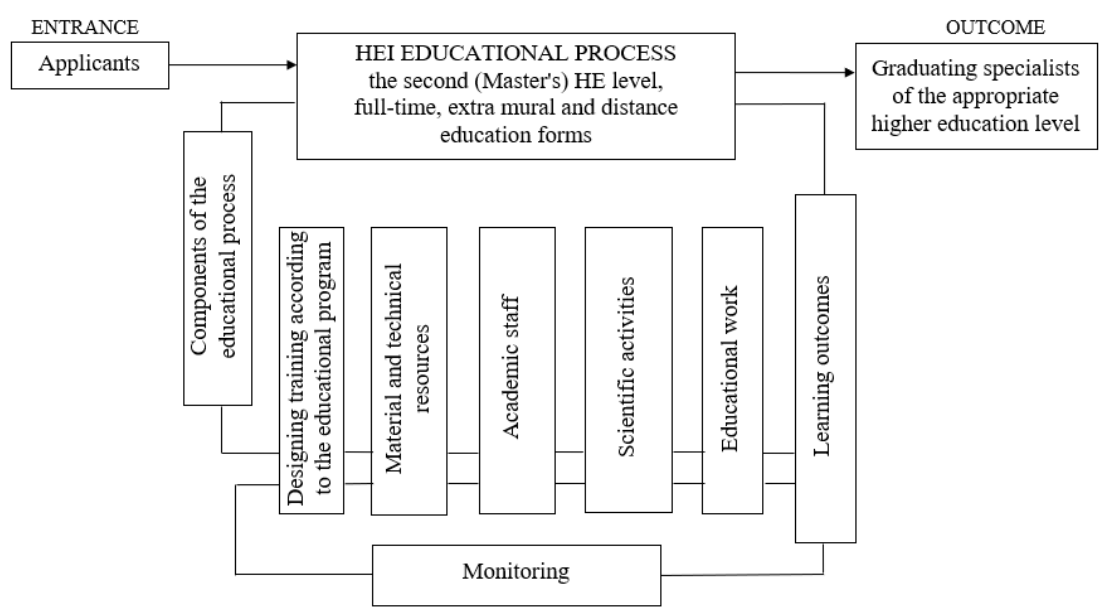

\section{Figure 2. The educational process scheme of the second master's HE level}

To build a mathematical model, an active experiment, a qualimetric approach, and a method of regression analysis have been used. The model has been built according to a specially designed scheme (Figure 3).

As seen from the figure, it consisted of five stages. Each of the stages is responsible for the individual components of the model and allows us to determine its statistical characteristics as a whole and to draw a conclusion about the possibility of its practical use.

In the first stage, with the help of the "HEI Experts" [29] software, a group of experts of 7 people was formed. Their competence was determined. According to a specially developed survey, the experts were checked for mutual agreement and instructed on conducting the assessment.

In the second stage, for each component of the educational process (see figure 2) the groups of their evaluation indicators were identified. In our case, to estimate the educational process of the second master's level, there were six groups. They are:

- compliance of applicants (bachelors) with the requirements of the educational program; 
Ganna Khimicheva, Antonina Volivach

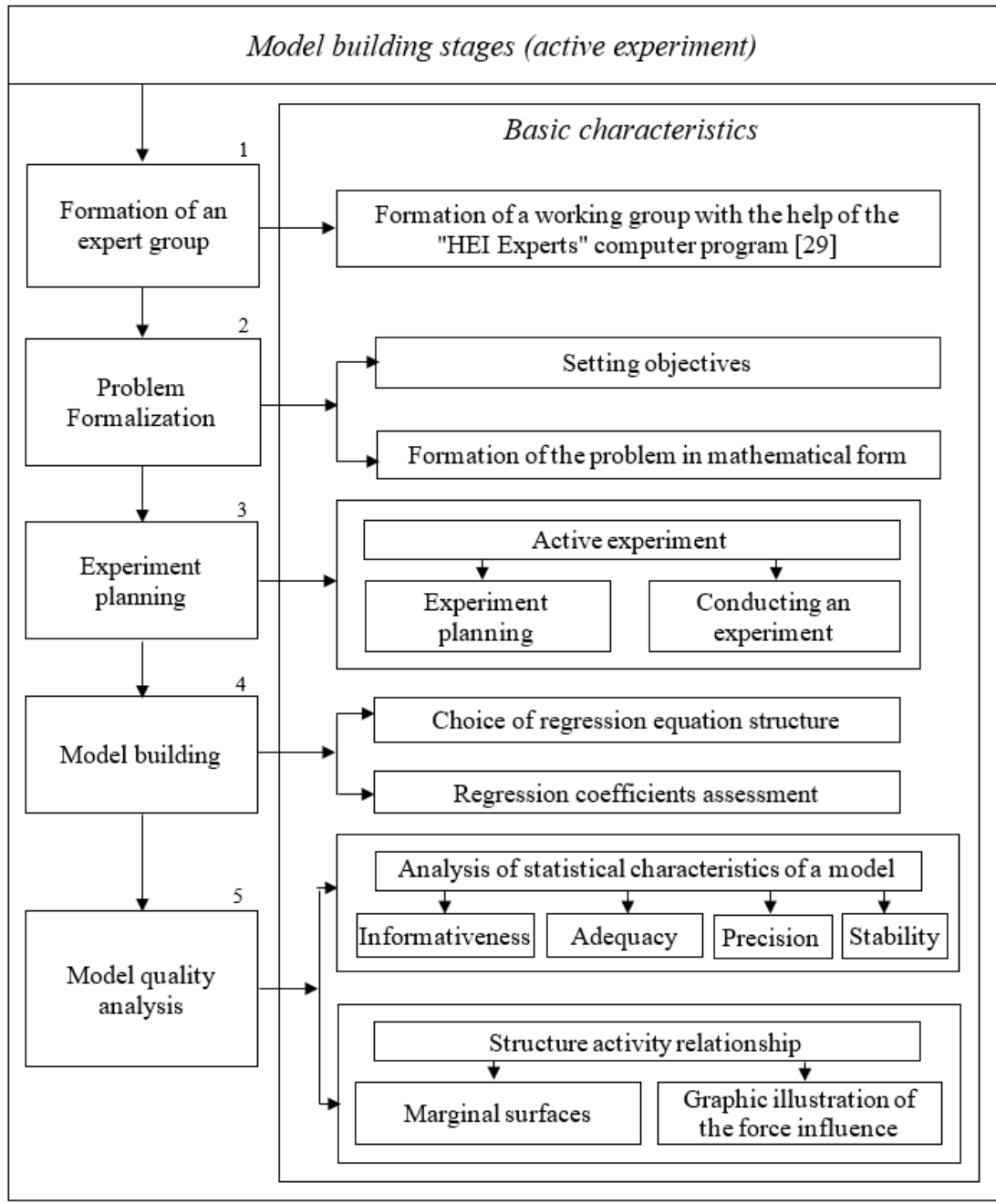

Figure 3. The scheme of a mathematical model construction for estimating the probability of risk of incompetent specialist graduation (conditional EP) 
- compliance with the educational process performed according to the requirements of the educational program;

- compliance of material and technical resources of the educational process with the educational program components;

- compliance of the academic staff with the licensing requirements;

- compliance of scientific activity with the professional direction;

- compliance of graduates with competencies acquired following the educational program.

Then, using the method of pairwise comparison, according to a specially designed questionnaire, the experts selected individual indicators, which further assessed the probability of risk. These indicators included: the adequacy of applicants (Bachelors) to the second Master's level of HE; compliance with the awareness of the educational program; compliance of the EP with the mission and strategy of HEI; compliance of the educational process with the organizational and methodological requirements of the EP; compliance with the planned terms of updating and implementation of laboratory equipment using information technology; compliance of the academic staff with the licensing requirements; correspondence of the scientific research level of the academic staff in the EP professional orientation; the level of students' involvement in scientific activities; the level of consideration of the labor market, employers (stakeholders) requirements in the EP.

These indicators characterize the components of the educational process (educational program) and meet the requirements of international "Standards and Recommendations for Quality Assurance in the European Higher Education Area" (ESG) [1].

To transform the qualitative characteristics of these indicators into quantitative ones, it was proposed to use a ranking scale. This allowed us to determine the levels of compliance and their quantification (Table 1).

In the third stage, the number of experimental variants was first calculated. In our case, this is the number of conditional EP. The calculation was performed according to formula (1) given in the source [30]:

$$
\text { Ncalc }=(1,5 \ldots 2)\left(1+\sum_{i=1}^{k}\left(S_{i}-1\right)\right),
$$

where $k$ - number of independent variables (factors);

$S_{i}$ - the number of levels of variation for each independent variable. 
Table 1

Assessment of conditional EPs compliance levels

\begin{tabular}{|c|c|c|c|c|}
\hline № & $\begin{array}{l}\text { Single indicators } \\
\text { of the educational process } \\
\text { quality of conditional EP }\end{array}$ & Regressors & $\begin{array}{l}\text { Complianc } \\
\text { according to }\end{array}$ & $\begin{array}{l}\text { els } \\
\text { scale }\end{array}$ \\
\hline \multirow{3}{*}{1} & \multirow{3}{*}{$\begin{array}{l}\text { the adequacy of applicants } \\
\text { (Bachelors) to the second Master's } \\
\text { level of HE }\end{array}$} & \multirow{3}{*}{$X_{1}$} & low & 1 \\
\hline & & & middle & 2 \\
\hline & & & high & 3 \\
\hline \multirow{3}{*}{2} & \multirow{3}{*}{$\begin{array}{l}\text { compliance with awareness } \\
\text { of the educational program }\end{array}$} & \multirow{3}{*}{$\mathrm{X}_{2}$} & low & 1 \\
\hline & & & middle & 2 \\
\hline & & & high & 3 \\
\hline \multirow{2}{*}{3} & \multirow{2}{*}{$\begin{array}{l}\text { compliance of the EP } \\
\text { with HEI mission and strategy }\end{array}$} & \multirow{2}{*}{$\mathrm{X}_{3}$} & low & 1 \\
\hline & & & high & 3 \\
\hline \multirow{3}{*}{4} & \multirow{3}{*}{$\begin{array}{l}\text { educational process compliance } \\
\text { with the organizational } \\
\text { and methodological requirements } \\
\text { of the EP }\end{array}$} & \multirow{3}{*}{$\mathrm{X}_{4}$} & low & 1 \\
\hline & & & middle & 2 \\
\hline & & & high & 3 \\
\hline \multirow{3}{*}{5} & \multirow{3}{*}{$\begin{array}{l}\text { compliance with the planned } \\
\text { terms of laboratory equipment } \\
\text { update and implementation using } \\
\text { information technology }\end{array}$} & \multirow{3}{*}{$\mathrm{X}_{5}$} & low & 1 \\
\hline & & & middle & 2 \\
\hline & & & high & 3 \\
\hline \multirow{3}{*}{6} & \multirow{3}{*}{$\begin{array}{l}\text { compliance of the academic staff } \\
\text { with the licensing requirements }\end{array}$} & \multirow{3}{*}{$\mathrm{X}_{6}$} & low & 1 \\
\hline & & & satisfactory & 2 \\
\hline & & & sufficient & 3 \\
\hline \multirow{3}{*}{7} & \multirow{3}{*}{$\begin{array}{l}\text { correspondence of the scientific } \\
\text { research level of the academic } \\
\text { staff in the EP professional } \\
\text { orientation }\end{array}$} & \multirow{3}{*}{$\mathrm{X}_{7}$} & low & 1 \\
\hline & & & middle & 2 \\
\hline & & & high & 3 \\
\hline \multirow{3}{*}{8} & \multirow{3}{*}{$\begin{array}{l}\text { the level of students' involvement } \\
\text { in scientific activities }\end{array}$} & \multirow{3}{*}{$\mathrm{X}_{8}$} & low & 1 \\
\hline & & & middle & 2 \\
\hline & & & high & 3 \\
\hline \multirow{3}{*}{9} & \multirow{3}{*}{$\begin{array}{l}\text { the level of consideration } \\
\text { of the labor market, employers } \\
\text { (stakeholders) requirements } \\
\text { in the EP }\end{array}$} & \multirow{3}{*}{$\mathrm{X}_{9}$} & low & 1 \\
\hline & & & satisfactory & 2 \\
\hline & & & sufficient & 3 \\
\hline
\end{tabular}


In this case, the distribution of the relative strength of the effects responsible for the process occurs exponentially.

Next, the method of pseudo-random LP- $\tau$ numbers uniformly distributed in multidimensional space was used to construct the matrix of the experimental plan. The robust plan of the experiment is given in (Table 2).

Table 2

The robust plan of the experiment

\begin{tabular}{|c|c|c|c|c|c|c|c|c|c|}
\hline $\begin{array}{c}\text { № of } \\
\text { exp. }\end{array}$ & $\mathbf{X}_{\mathbf{1}}$ & $\mathbf{X}_{\mathbf{2}}$ & $\mathbf{X}_{\mathbf{3}}$ & $\mathbf{X}_{\mathbf{4}}$ & $\mathbf{X}_{\mathbf{5}}$ & $\mathbf{X}_{\mathbf{6}}$ & $\mathbf{X}_{\mathbf{7}}$ & $\mathbf{X}_{\mathbf{8}}$ & $\mathbf{X}_{\mathbf{9}}$ \\
\hline 1 & 0,5 & 0,5 & 0,5 & 0,5 & 0,5 & 0,5 & 0,5 & 0,5 & 0,5 \\
\hline 2 & 0,25 & 0,75 & 0,25 & 0,75 & 0,25 & 0,75 & 0,25 & 0,75 & 0,75 \\
\hline 3 & 0,75 & 0,25 & 0,75 & 0,25 & 0,75 & 0,25 & 0,75 & 0,25 & 0,25 \\
\hline 4 & 0,125 & 0,625 & 0,875 & 0,875 & 0,625 & 0,125 & 0,375 & 0,375 & 0,875 \\
\hline 5 & 0,625 & 0,125 & 0,375 & 0,375 & 0,125 & 0,625 & 0,875 & 0,875 & 0,375 \\
\hline 6 & 0,375 & 0,375 & 0,625 & 0,125 & 0,875 & 0,875 & 0,125 & 0,625 & 0,125 \\
\hline 7 & 0,875 & 0,875 & 0,125 & 0,625 & 0,375 & 0,375 & 0,625 & 0,125 & 0,625 \\
\hline 8 & 0,0625 & 0,9375 & 0,6875 & 0,3125 & 0,1875 & 0,0625 & 0,4375 & 0,5625 & 0,8125 \\
\hline 9 & 0,5625 & 0,4375 & 0,1875 & 0,8125 & 0,6875 & 0,5625 & 0,9375 & 0,0625 & 0,3125 \\
\hline 10 & 0,3125 & 0,1875 & 0,9375 & 0,5625 & 0,4375 & 0,8125 & 0,1875 & 0,3125 & 0,0625 \\
\hline 11 & 0,8125 & 0,6875 & 0,4375 & 0,0625 & 0,9375 & 0,3125 & 0,6875 & 0,8125 & 0,5625 \\
\hline 12 & 0,1875 & 0,3125 & 0,3125 & 0,6875 & 0,5625 & 0,1875 & 0,0625 & 0,9375 & 0,1875 \\
\hline 13 & 0,6875 & 0,8125 & 0,8125 & 0,1875 & 0,0625 & 0,6875 & 0,5625 & 0,4375 & 0,6875 \\
\hline 14 & 0,4375 & 0,5625 & 0,0625 & 0,4375 & 0,8125 & 0,9375 & 0,3125 & 0,1875 & 0,9375 \\
\hline 15 & 0,9375 & 0,0625 & 0,5625 & 0,9375 & 0,3125 & 0,4375 & 0,8125 & 0,6875 & 0,4375 \\
\hline 16 & 0,03125 & 0,53125 & 0,40625 & 0,21875 & 0,46875 & 0,28125 & 0,96875 & 0,28125 & 0,09375 \\
\hline
\end{tabular}

This plan is based on the evaluation of each of the 16 conditional educational programs of the second Master's level of higher education, according to nine single indicators (see Table 1). This allowed us to reliably determine the effectiveness (efficiency) of the EP, i.e. to determine the potential for the risk of incompetent specialist graduation.

To construct a working matrix, first, the data of the robust plan of the experiment (Table 2) were transformed into natural by formula (2) given in the source [30]: 


$$
X_{i u}=X_{\text {imin }}+\xi_{\text {iu }}\left(X_{\text {imax }}-X_{\text {imin }}\right),
$$

where $X_{i u}-$ estimated natural value of $i$-factor for $u$-experiment (conditional EP);

$X_{\text {imin }}-$ minimum value of $i$-factor;

$X_{\text {imax }}$ - maximum value of $i$-factor;

$\xi_{i u}$ - coded (in the range from 0 to 1 ) value of $i$-factor for $u$-experiment (conditional EP).

PRIAM (planning, regression and model analysis) software was used to construct the working matrix of the experiment [31]. The obtained results are summarized in (Table 3 ).

Table 3

Design matrix

\begin{tabular}{|c|c|c|c|c|c|c|c|c|c|}
\hline 告 & $X_{1}$ & $\mathbf{X}_{2}$ & $\mathbf{X}_{3}$ & $\mathbf{X}_{4}$ & $\mathbf{X}_{5}$ & $X_{6}$ & $\mathbf{X}_{7}$ & $X_{8}$ & $X_{9}$ \\
\hline 1 & middle & middle & low & middle & middle & middle & middle & middle & satisfactory \\
\hline 2 & low & high & low & high & low & high & low & high & sufficient \\
\hline 3 & high & low & high & low & high & low & high & low & low \\
\hline 4 & low & middle & high & high & middle & low & middle & middle & sufficient \\
\hline 5 & middle & low & low & middle & low & middle & high & high & satisfactory \\
\hline 6 & middle & middle & high & low & high & high & low & middle & low \\
\hline 7 & high & high & low & middle & middle & middle & middle & low & satisfactory \\
\hline 8 & low & high & high & low & low & low & middle & middle & sufficient \\
\hline 9 & middle & middle & low & high & high & middle & high & low & low \\
\hline 10 & low & low & high & middle & middle & high & low & low & low \\
\hline 11 & high & high & low & low & high & low & high & high & satisfactory \\
\hline 12 & low & low & low & high & middle & low & low & high & low \\
\hline 13 & high & high & high & low & low & high & middle & middle & sufficient \\
\hline 14 & middle & middle & low & middle & high & high & low & low & sufficient \\
\hline 15 & high & low & high & high & low & middle & high & high & satisfactory \\
\hline 16 & low & middle & low & low & middle & low & high & low & low \\
\hline
\end{tabular}


This matrix consists of different evaluation characteristics of 16 conditional EPs by nine quality indicators (regressors), which have different effects on the probability of risk of incompetent specialist graduation.

Then, according to a specially developed survey the potential for risk of incompetent specialist graduation for each conditional educational program was estimated in percentage by an expert group (formed at the first stage). According to the results of expert evaluation, the probabilistic percentage of risk of incompetent specialist graduation was determined (Table 4).

Table 4

The results of expert evaluation

\begin{tabular}{|c|c|c|c|c|c|c|c|c|}
\hline $\begin{array}{c}\text { № of } \\
\text { conditional } \\
\begin{array}{c}\text { EP } \\
\text { evaluation } \\
\text { experiment }\end{array}\end{array}$ & \multicolumn{7}{|c|}{ Expert evaluations, \% } & \multirow{2}{*}{ Y, \% } \\
\cline { 2 - 9 } & $\mathbf{E}_{\mathbf{1}}$ & $\mathbf{E}_{\mathbf{2}}$ & $\mathbf{E}_{\mathbf{3}}$ & $\mathbf{E}_{\mathbf{4}}$ & $\mathbf{E}_{\mathbf{5}}$ & $\mathbf{E}_{\mathbf{6}}$ & $\mathbf{E}_{\mathbf{7}}$ & \\
\hline 1 & 32 & 40 & 37 & 36 & 34 & 38 & 35 & 36 \\
\hline 2 & 30 & 25 & 25 & 23 & 28 & 25 & 26 & 26 \\
\hline 3 & 34 & 38 & 40 & 38 & 39 & 36 & 35 & 37 \\
\hline 4 & 23 & 25 & 30 & 24 & 30 & 27 & 28 & 27 \\
\hline 5 & 32 & 36 & 38 & 35 & 35 & 37 & 35 & 35 \\
\hline 6 & 28 & 35 & 28 & 28 & 30 & 31 & 33 & 30 \\
\hline 7 & 34 & 28 & 30 & 31 & 31 & 27 & 32 & 30 \\
\hline 8 & 39 & 43 & 44 & 41 & 40 & 38 & 38 & 40 \\
\hline 9 & 30 & 29 & 32 & 30 & 28 & 35 & 29 & 30 \\
\hline 10 & 43 & 45 & 46 & 45 & 39 & 42 & 40 & 43 \\
\hline 11 & 25 & 18 & 20 & 22 & 25 & 23 & 24 & 22 \\
\hline 12 & 45 & 48 & 50 & 49 & 46 & 45 & 50 & 48 \\
\hline 13 & 20 & 22 & 19 & 21 & 15 & 18 & 21 & 19 \\
\hline 14 & 31 & 29 & 28 & 33 & 35 & 28 & 30 & 31 \\
\hline 15 & 19 & 15 & 20 & 22 & 20 & 17 & 18 & 19 \\
\hline 16 & 55 & 51 & 50 & 53 & 49 & 52 & 49 & 51 \\
\hline
\end{tabular}

To ensure the estimation reliability, the results (Table 4) were checked for consistency. According to the results of the inspection: the concordance coefficient is $\mathrm{W}=0.95$; the critical value of the beta distribution $\mathrm{Wk}=0.23$; critical value $\mathrm{W}=0.24$. 
That is, it fully confirms the reliability of the results of expert evaluation.

In the fourth stage, the structure of the regression equation was first selected using PRIAM software and data (Table 4). Then the regression coefficients were estimated and model (3) was constructed.

The resulting model has the following form:

$$
\begin{aligned}
\mathrm{Y}= & 32,4479-8,78047 \mathrm{x}_{1}-4,80125 \mathrm{x}_{9}-2,2576 \mathrm{x}_{4}-5,00888 \mathrm{z}_{4}- \\
& -3,56659 \mathrm{x}_{6}+3,46327 \mathrm{x}_{3} \mathrm{z}_{5}-1,11123 \mathrm{x}_{8}-0,567734 \mathrm{x}_{2} \mathrm{x}_{7},
\end{aligned}
$$

where: $\mathrm{x}_{1}=0,941176\left(\mathrm{X}_{1}-0,9375\right)$;

$\mathrm{x}_{2}=\left(\mathrm{X}_{2}-1\right)$;

$\mathrm{x}_{3}=1,77778\left(\mathrm{X}_{3}-0,4375\right)$;

$\mathrm{x}_{4}=0,941176\left(\mathrm{X}_{4}-0,9375\right)$;

$\mathrm{z}_{4}=1,64632\left(x_{4}^{2}-0,0907563 * \mathrm{x}_{4}-0,605536\right)$;

$\mathrm{x}_{5}=\left(\mathrm{X}_{5}-1\right)$;

$\mathrm{z}_{5}=1,6\left(x_{5}^{2}-0,625\right)$;

$\mathrm{x}_{6}=0,941176\left(\mathrm{X}_{6}-0,9375\right)$;

$\mathrm{x}_{7}=0,941176\left(\mathrm{X}_{7}-1,0625\right)$;

$\mathrm{x}_{8}=0,941176\left(\mathrm{X}_{8}-0,9375\right)$;

$\mathrm{x}_{9}=0,941176\left(\mathrm{X}_{9}-0,9375\right)$.

In the fifth stage, the statistical characteristics of the model were analyzed. Summary results of the analysis are given in (Table 5).

Thus, as seen from (Table 5), the model is informative, adequate and stable, both in structure and in calculations.

To determine the effectiveness (efficiency) of the educational program, i.e. to determine the probability of the risk of incompetent specialist graduation, marginal surfaces were constructed (see Figure 4-7).

This approach allowed us to identify and analyze the combined effect of regressors (quality indicators) on the probability of risk of incompetent specialist graduation. Analysis of the graphical result of the surfaces showed that the combined effect of regressors can both significantly increase and decrease the probability of the risk of incompetent specialist graduation.

For clarity, the dependence of the regressors (quality indicators) share on the probability of competent/incompetent specialist graduation was constructed (Figure 8).

As can be seen from the figure, the greatest impact on the competence of the specialist have such indicators as the adequacy of applicants (Bachelors) 
Table 5

Statistical characteristics of the model built according to the plan of the experiment

\begin{tabular}{|c|c|c|c|}
\hline Characteristic & Name & Legend & Value \\
\hline \multirow{9}{*}{ Informativeness } & Multiple correlation coefficient & $\mathrm{R}$ & 0,969504 \\
\hline & $\begin{array}{l}\text { Estimated value of Fisher criterion to } \\
\text { verify the significance of } \mathrm{R}\end{array}$ & $\mathrm{F}_{\mathrm{R}}$ & 13,6932 \\
\hline & $\begin{array}{l}\text { The critical value of the Fisher } \\
\text { criterion to verify the significance } \\
\text { of } \mathrm{R}\end{array}$ & $\mathrm{F}_{\text {cr R }}$ & 2,02954 \\
\hline & \multirow{2}{*}{ Degrees of freedom } & $\mathrm{n}$ & 8 \\
\hline & & $\mathrm{n}$ & 103 \\
\hline & $\begin{array}{l}\text { The scattering fraction explained by } \\
\text { the model }\end{array}$ & $\mathrm{R}^{2}$ & 0,939938 \\
\hline & Box-Wetz criterion & $\mathrm{g}$ & 1 \\
\hline & $\begin{array}{l}\text { Hypothesis about the multiple } \\
\text { correlation coefficient significance }\end{array}$ & - & accepted \\
\hline & Informativeness level & - & satisfactory \\
\hline \multirow{7}{*}{ Adequacy } & Residual variance & $\mathrm{S}_{\text {res var }}^{2}$ & 11,1415 \\
\hline & Reproducibility variance & $\mathrm{S}_{\text {rep var }}^{2}$ & 5,93156 \\
\hline & $\begin{array}{l}\text { Estimated value of Fisher criterion to } \\
\text { test adequacy }\end{array}$ & $\mathrm{F}_{\mathrm{ad}}$ & 1,87834 \\
\hline & $\begin{array}{l}\text { Critical value of Fisher criterion to } \\
\text { test adequacy }\end{array}$ & $\mathrm{F}_{\text {cr val }}$ & 2,10647 \\
\hline & \multirow{2}{*}{ Degrees of freedom (n } & $\mathrm{n}$ & 8 \\
\hline & & $\mathrm{n}$ & 7 \\
\hline & Hypothesis of the adequacy & - & accepted \\
\hline \multirow[t]{2}{*}{ Accuracy } & $\begin{array}{l}\text { Average accuracy of data description } \\
\text { in percent deviation }\end{array}$ & $\%$ & 5,8347 \\
\hline & Average absolute approximation error & $\mathrm{D}$ & 1,75521 \\
\hline \multirow{4}{*}{ Stability } & COND (conditionality number) & & 1,75344 \\
\hline & conclusion & - & good \\
\hline & $\begin{array}{l}\text { Part of the explanation by dubious } \\
\text { regressors }\end{array}$ & $\%$ & 19,38 \\
\hline & conclusion & - & satisfactory \\
\hline $\begin{array}{l}\text { Level of } \\
\text { significance }\end{array}$ & $\alpha$ & - & 0,05 \\
\hline
\end{tabular}




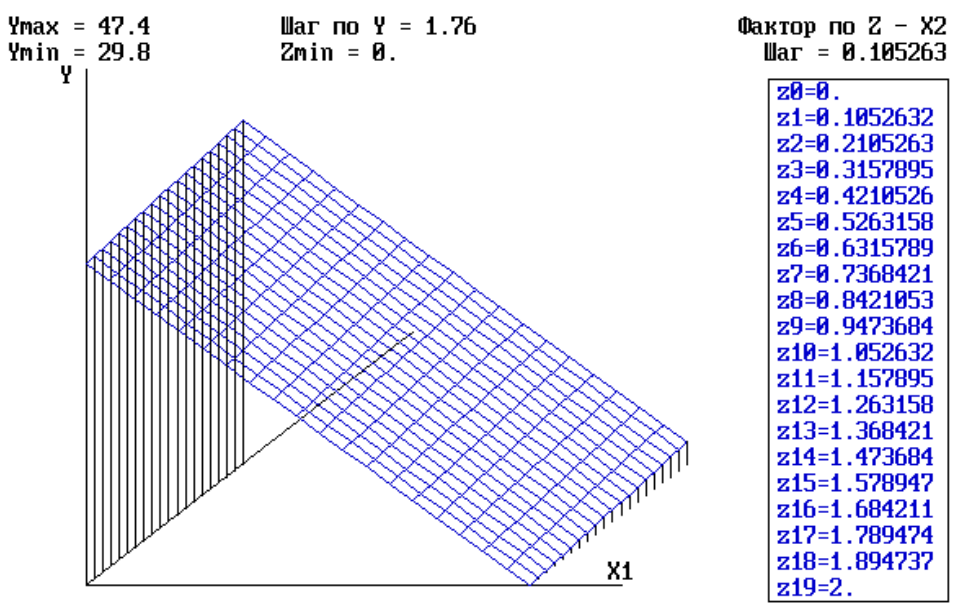

Ymin\&Xmin\&Zmin $X_{\min }=0 \quad \mathrm{X}_{\max }=2$ Шаг по $\mathrm{X}=0.1$

Figure 4. Marginal surface of the combined effect of regressors $X_{1}$ and $X_{2}$ on the probability of risk of incompetent specialist graduation

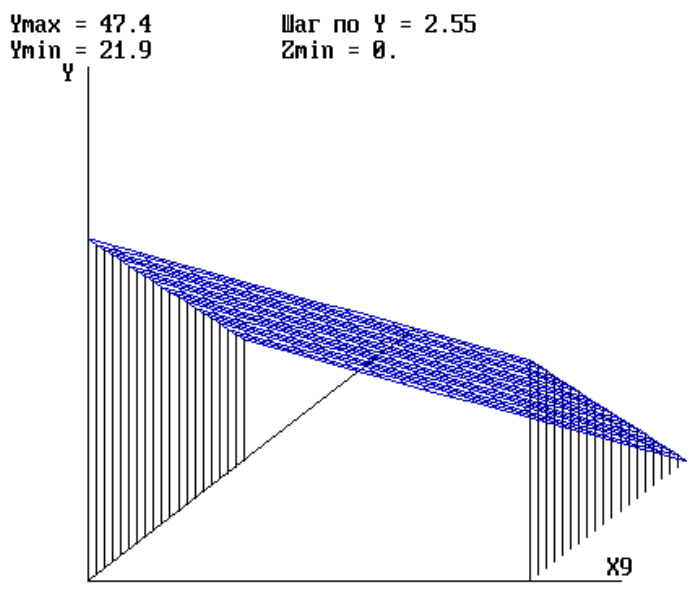

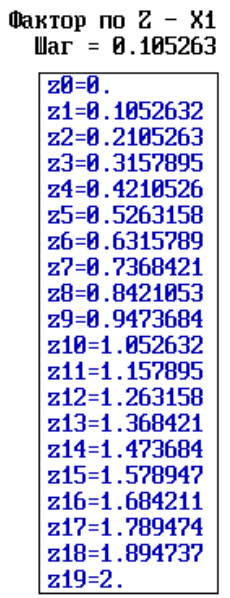

Ymin\&Xmin\&Zmin $\quad X \min =0 \quad X_{\max }=2$ Шаг по $X=0.1$

Figure 5. Marginal surface of the combined effect of regressors $X_{9}$ and $X_{1}$ on the probability of risk of incompetent specialist graduation 


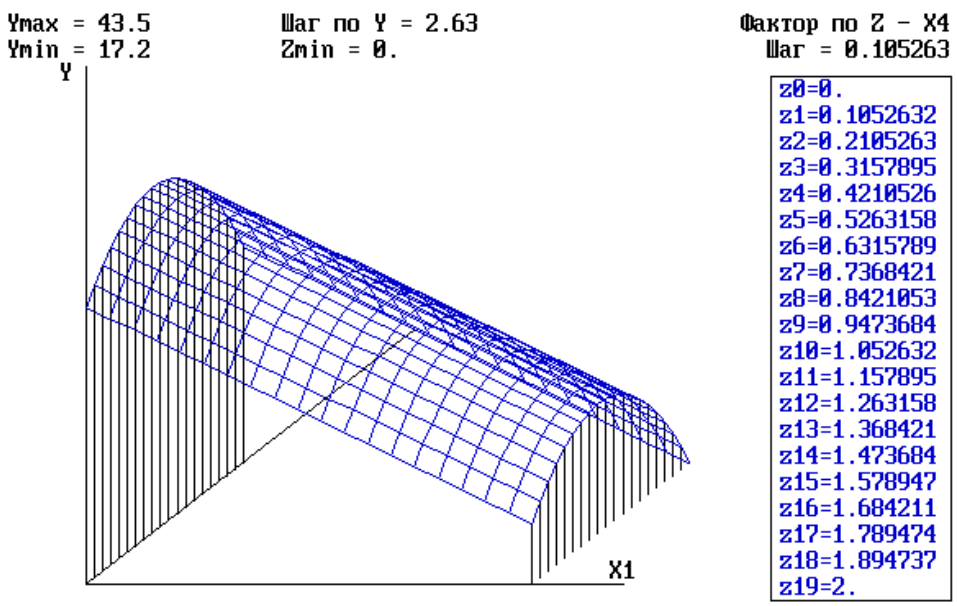

Ymin\&Xmin\&Zmin $\quad X_{\min }=0 \quad \mathrm{Xmax}_{2}=2$ Шаг по $\mathrm{X}=0.1$

Figure 6. Marginal surface of the combined effect of regressors $X_{1}$ and $\mathrm{X}_{4}$ on the probability of risk of incompetent specialist graduation

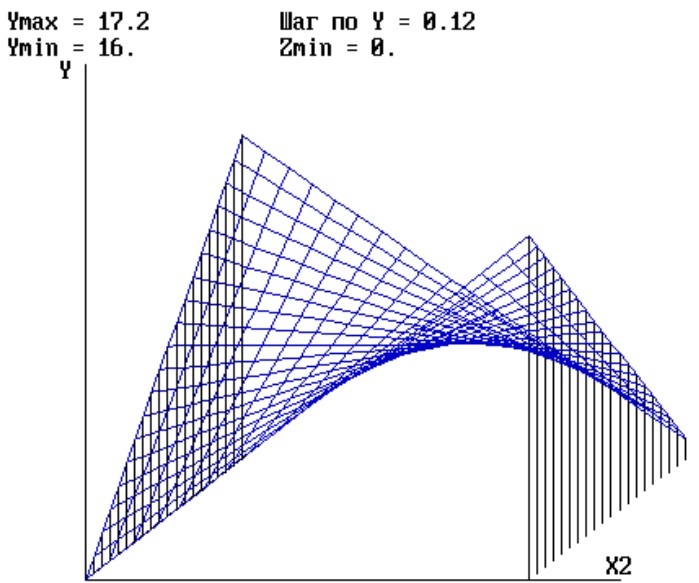

Шактор по $z-x 7$
Шаг $=0.105263$
\begin{tabular}{|l|}
\hline$z 0=0$. \\
$z 1=0.1952632$ \\
$z 2=0.2105263$ \\
$z 3=0.3157895$ \\
$z 4=0.4210526$ \\
$z 5=0.5263158$ \\
$z 6=0.6315789$ \\
$z 7=0.7368421$ \\
$z 8=0.8421053$ \\
$z 9=0.9473684$ \\
$z 10=1.052632$ \\
$z 11=1.157895$ \\
$z 12=1.263158$ \\
$z 13=1.368421$ \\
$z 14=1.473684$ \\
$z 15=1.578947$ \\
$z 16=1.684211$ \\
$z 17=1.789474$ \\
$z 18=1.894737$ \\
$z 19=2$. \\
\hline
\end{tabular}

Ymin\&Xmin\&Zmin $\quad X \min =0 \quad$ Xmax $=2$ Шаг по $X=0.1$

Figure 7. Marginal surface of the combined effect of regressors $\mathrm{X}_{2}$ and $X_{7}$ on the probability of risk of incompetent specialist graduation 


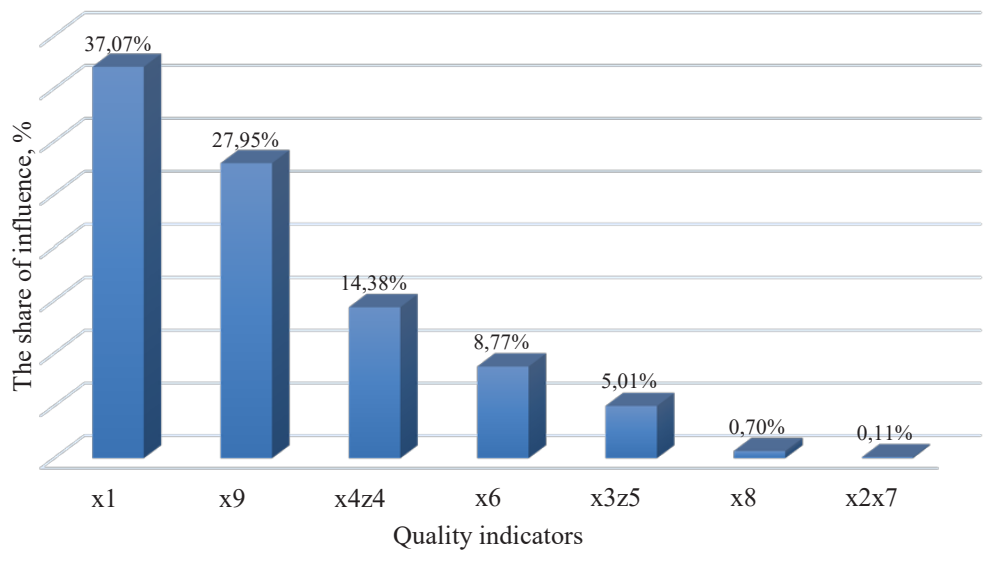

Figure 8. Distribution of quality indicators (regressors) influence on the probability of competent/incompetent specialist graduation

to the second Master's level of HE and the level of consideration of the labor market, employers (stakeholders) requirements in the EP. This is because they are fundamental to the formation of future specialist competence and the educational process effectiveness.

Thus, the proposed model allows us to estimate the factors influencing the efficiency (effectiveness) of the educational process and the probability of the risk of incompetent specialist graduation.

\section{Conclusions}

It has been proved that the evaluation of the educational program effectiveness (efficiency) should be carried out within six groups of indicators of the educational process quality by nine single indicators which allow us to estimate the probability of risk of incompetent specialist graduation.

Sixteen conditional educational programs have been formed, and experimental researches have been carried out on their basis.

With the help of pseudo-random LP- $\tau$ numbers, the robust plan of the experiment has been made, and the working matrix of the estimation of 
16 conditional educational programs has been formed. Expert methods have determined the probable percentage of the risk of incompetent specialist graduation. Subsequently, the obtained data were used to build a mathematical model.

With the help of PRIAM software, a mathematical regression model has been built, which allows us to predict the probability of the risk of incompetent specialist graduation. The model is adequate, informative, and stable, both in structure and in calculations.

Based on the results of the constructed model, the influence of the "entry" and "exit" indicators of the educational process on the probability of the risk of competent/incompetent specialist graduation has been determined. It has been found that the competence of future specialists is mostly influenced by the following indicators: the adequacy of applicants (Bachelors) to the second Master's level of HE and the level of consideration of the labor market, employers (stakeholders) requirements in the EP. In this case, the higher the value of these indicators at the "input", the better the level of competence of the graduate at the "output" and vice versa.

The application of the principles, methods, and approaches presented in the work allows higher education institutions to estimate the factors (factors) that negatively affect educational activities. This allows HEIs to identify "weaknesses" on time and develop organizational and technical measures to prevent and reduce the risks of their activities in general. That is, increase their competitiveness.

\section{References:}

1. Standards and Guidelines for Quality Assurance in the European Higher Education Area. Brussels, Belgium: European Association for Quality Assurance in Higher Education (2015). enqa.eu. Retrieved from: https://enqa.eu/wp-content/ uploads/2015/11/ESG_2015.pdf

2. Vitlinskyi V.V., Nakonechnyi S.I. (1996). Ryzyk u menedzhmenti [Risk in management]. Kyiv: TOV «Borysfen - M», 336 p. (in Ukrainian)

3. Dubrov A.M., Lagosha B.A., Khrustalev E.Yu., Baranovskaya T.P. (2001). Modelirovanie riskovykh situatsiy v ekonomike i biznese [Modeling risk situations in economics and business]. (in Ukrainian)

4. Kaleniuk I.S., Kuklin O.V., Yamkovyi V.A. (2015). Suchasni ryzyky rozvytku vyshchoi osvity v Ukraini [Modern risks of higher education development in Ukraine]. Ekonomika Ukrain, no. 2(639), pp. 70-83. (in Ukrainian)

5. Verbitska I.I. (2013). Ryzyk-menedzhment yak suchasna systema upravlinnia ryzykamy pidpryiemnytskykh struktur [Risk management as a modern risk 
management system of business structures]. Stalyi rozvytok ekonomiky, no. 5(22), pp. 282-291. (in Ukrainian)

6. Rashkevych Yu.M. (2016). Metodychni rekomendatsii dlia rozroblennia profiliv stupenevykh prohram, vkliuchaiuchy prohramni kompetentnosti ta prohramni rezultaty navchannia [Methodical recommendations for making profiles of degree programs, including program competencies and program learning outcomes] per. z anhl. Natsionalnoho eksperta z reformuvannia vyshchoi osvity Prohramy Erazmus+. Kyiv: TOV «Polihraf plius», 80 p. (in Ukrainian)

7. Volivach A.P., Khimicheva G.I. (2017). Zastosuvannia mizhnarodnykh standartiv ISO 9001:2015 ta ISO 31000:2009 dlia pobudovy intehrovanoi systemy upravlinnia VNZ [Application of international standards ISO 9001:2015 and ISO 31000:2009 to build an integrated university management system]. Upravlinnia yakistiu v osviti ta promyslovosti: dosvid, problemy ta perspektyvy: tezy dopovidei III Mizhnarodnoi naukovo-praktychnoi konferentsii pamiati profesora Stoliarchuka. Lviv: Lvivska politekhnika, p. 45. (in Ukrainian)

8. Volivach A.P., Khimicheva G.I. (2018). Osoblyvosti zastosuvannia standartiv ISO 31000 dlia pobudovy intehrovanykh system upravlinnia [Features of application of ISO 31000 standards for construction of integrated control systems]. Tezy dopovidei KhVII Vseukrainskoi naukovoi konferentsii molodykh uchenykh ta studentiv, «Naukovi rozrobky molodi na suchasnomu etapi. Kyiv: KNUTD, tom 2, pp. 377-378. (in Ukrainian)

9. Volivach A.P., Khimicheva G.I. (2017). Vyznachennia faktoriv ryzykiv u vidpovidnosti do modeli SUIa VNZ za vymohamy DSTU ISO 9001:2015 [Determination of risk factors in accordance with the QMS model of the university according to the requirements of DSTU ISO 9001:2015]. Mizhnar. konf. «Innovatsiini tekhnolohii v nautsi ta osviti. Yevropeiskyi dosvid». TOM I. m. Viden, Avstriia, pp. 48-57. (in Ukrainian)

10. Trishch R.M., Kiporenko H.S., Kim, N.I. \& Denysenko A.M. (2016). Otsiniuvannia ryzykiv funktsionuvannia systemy upravlinnia yakistiu (DSTU ISO 9001:2015) vyshchykh navchalnykh zakladiv [The assessment of functioning of the quality management system (DSTU ISO 9001:2015) of higher educational establishments risks]. Systemy upravlinnia, navihatsii ta zviazku, no. 2(38), pp. 133-136. (in Ukrainian)

11. Dolzhanskyi A.M., Proidak Yu.S. \& Revenko O.O. (2016). Zastosuvannia metodiv analizu ta otsinky ryzykiv $\mathrm{v}$ diialnosti vyshchoho navchalnoho zakladu [Application of methods of analysis and risk assessment in the activity of a higher educational institution]. Nauka ta innovatsii, no. 12(5), pp. 5-13. (in Ukrainian)

12. Donets O.M., Savelieva T.V., Uretska Yu.I. (2011). Vykorystannia mizhnarodnykh standartiv v upravlinnia ryzykamy [Use of International Standards in Risk Management]. Upravlinnia rozvytkom skladnykh system, no. 6, pp. 36-42. (in Ukrainian)

13.Proskura V.F., Bilak R.H. (2017). Metodolohichni pidkhody do upravlinnia ryzykamy [Methodological approaches to risk management]. Ekonomika i suspilstvo, vol. 9, pp. 599-607. (in Ukrainian)

14.Hoerl A.E., Kennard R.W. (1970). Ridge regression: biased estimation for non-orthogonal problems. Technometrics, vol. 12, pp. 55-67. 
15. Radchenko S.G. (2012). Metody nailuchshego resheniya regressionnykh zadach [Methods for the best solution of regression problems]. Visnik Natsional'nogo aviatsiynogo universitetu, vol. 1(50), pp. 32-39.

16. Radchenko S.G. (2011). Formalizatsiya postanovki mnogofaktornogo eksperimental'nogo issledovaniya [Formalization of the formulation of a multifactorial experimental study]. Matematichni mashini i sistemi, vol. 1, p. 96-102.

17. Radchenko S.G., Lapach S.M. (2018). Doslidzhennya ta modelyuvannya tekhnologichnogo protsesu kontaktnogo zvaryuvannya trub [Research and modeling of technological process of contact welding of pipes]. Tekhnichni nauki ta tekhnologii, vol. 3(13), pp. 114-121.

18. Hryniv T.T. (2008). Otsiniuvannia vplyvu bahatokh faktoriv ryzyku na investytsiinu pryvablyvist mashynobudivnoi haluzi na osnovi bahatofaktornoi matematychnoi modeli [Assessing the impact of many risk factors on the investment attractiveness of the engineering industry based on a multifactor mathematical model]. Visnyk Natsionalnoho universytetu "Lvivska politekhnika", vol. 633. Lohistyka, pp. 144-152.

19. Siminchenko I.P., Malyhin O.V. (2017). Bahatofaktorne statystychne modeliuvannia pry doslidzhenniprotsesiv u tekhnichnii obrobtsi metaliv [Multifactor statistical modeling in the study processes in the technical processing of metals]. Visnyk ZhDTU, vol. 2(80), pp. 151-154. (in Ukrainian)

20. Radchenko S.H. (2003). Bahatofaktorne matematychne modeliuvannia ta kompromisna optymizatsiia tekhnolohichnoho protsesu elektroeroziinoho proshyttia otvoriv [Multifactor mathematical modeling and compromise optimization of the technological process of EDM]. Matematychni mashyny $i$ systemy, vol. 3, 4, pp. 186-200 (in Ukrainian)

21. Maliarets L.M., Minienkova O.V. (2017). Vyrishennia problem bahatokryterialnosti $\mathrm{v}$ otsintsi diialnosti pidpryiemstva na osnovi metodiv bahatokryterialnoi optymizatsii [Solving problems of multicriteria in the assessment of the enterprise on the basis of methods of multicriteria optimization]. Problemy ekonomiky, vol. 1, pp. $421-427$.

22. Yeleiko V.I., Bodnar R.D. (2011). Ekonometrychnyi analiz diialnosti pidpryiemstv [Econometric analysis of enterprises]. Ternopil: Navchalna knyha «Bohdan», 365 p. (in Ukrainian)

23. Kuprienko N.V., Ponomareva O.A. \& Tikhonov D.V. (2008). Statisticheskie metody izucheniya svyazey. Korrelyatsionno-regressionnyy analiz [Statistical methods of studying connections. Correlation-regression analysis]. Sankt-Peterburg: Izd-vo politekhn. un-ta, $118 \mathrm{p}$.

24. Sahaidak M.P. (2015). Ekonomiko-matematychna model upravlinnia pidsystemoiu «Personal» u systemi vnutrishnoho marketynhu pidpryiemstva [Economic and mathematical model of management of the subsystem "Personnel" in the system of internal marketing of the enterprise]. Biznes Inform, no. 1, pp. 154-159.

25. Volivach A.P., Khimicheva G.I. (2019). Klasyfikatsiia ryzykiv navchalnoho protsesu na osnovi zastosuvannia metodu iierarkhii [Classification of risks of the educational process based on the application of the method of hierarchies]. Monografia Pokonfenrencyjna. Science, Research, Development. (Nauka, Yssledovanyia, Razvytye. № 19). (Republic of Malta), no. 19, pp. 96-106. 
26. Himicheva G.I., Volivach A.P. (2019). Assessment of the learning process risks at higher educational institutions in accordance with the DSTU ISO 31010:2013 requirements. Ocinjuvannja ryzykiv osvitn'ogo procesu ZVO zgidno z vymogamy DSTU ISO 31010:2013. New stages of develjpment of modern science in Ukraine and EU countries: monograph . edited by authors. 3rd ed. Riga, Latvia: «Baltija Publ», pp. 268-289. doi: 10.30525/978-9934-588-15-0-61

27. The Verkhovna rada of Ukraine (2019). Kryterii' : Dodatok do Polozhennja pro akredytaciju osvitnih program, za jakymy zdijsnjujet'sja pidgotovka zdobuvachiv vyshhoi' osvity (paragraph 6 section I) [Criteria: Annex to the Regulations on Accreditation of Educational Programs for Higher Education (Item 6 of Section I)]. Available at: http://zakon.rada.gov.ua/laws/show/z0880-19\#n182 (accessed 20.09.2020). (in Ukrainian)

28. Volivach A.P., Khimicheva G.I. (2020). Naukovyi tvir «Alhorytm otsiniuvannia ryzykiv na osnovi vymoh standartu DSTU ISO 31010:2013» [Scientific work "Algorithm for risk assessment based on the requirements of the standard DSTU ISO 31010: 2013"]. a. s. № 97089; biul. № 58.

29. Volivach A.P., Khimicheva G.I. (2020). Kompiuterna prohrama «Prohramnyi kompleks «Eksperty ZVO» dlia formuvannia ekspertnykh hrup v osvitnii haluzi» (skorochena nazva «Eksperty ZVO») [Computer program "Software complex" HEI Experts "for the formation of expert groups in the field of education" (abbreviated name "HEI Experts")]. a. s. № 95933, bjul. № 57.

30. Lapach S.M., Radchenko S.H. \& Halaida R.V. (2007). Matematychne modeliuvannia ta optymizatsiia tekhnolohichnykh system: Metod. Vkazivky do laborator.-kompiut. praktykumu dlia stud. spets. «Tekhnolohiia mashynobuduvannia» usikh form navchannia [Mathematical modeling and optimization of technological systems: Method. Instructions for the laboratory-computer. workshop for students. special "Engineering Technology" of all forms of education]. Kyiv: NTUU «KPI», 116 p.

31.Lapach S.N., Radchenko S.G. \& Babich P.N. (1993). Planyrovanye, rehressyja y analyz modelej PRIAM (PRYAM) [Planning, regression and analysis of PRIAM models]. Kataloh prohrammnыe produkty Ukrayny. Kiev, pp. 24-27. (in Russian) 